SPECIES IDENTIFICATION OF THE SHARK CATCHES LANDED IN THE WEST COAST OF SRI LANKA WITH SPECIAL REFERENCES TO THE SILKY SHARK Carcharhinus falciformis (Bibron,1839)

by

P. D. KAMAL DEWAPRIYA AMARASOORIYA 



\section{DECLARATION}

"The work described in this thesis was carried out by me under the supervision of Professor J. Jinadasa and Dr. Mrs. C. Amarasiri and a report on this has not been submitted to any University for another degree."

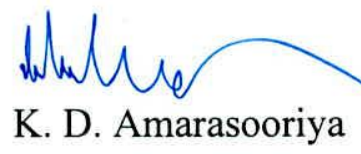




\section{DECLARATION OF THE SUPERVISORS}

"We certify that the above statement made by the candidate is true and that this thesis is suitable for submission to the University for the purpose of evaluation."

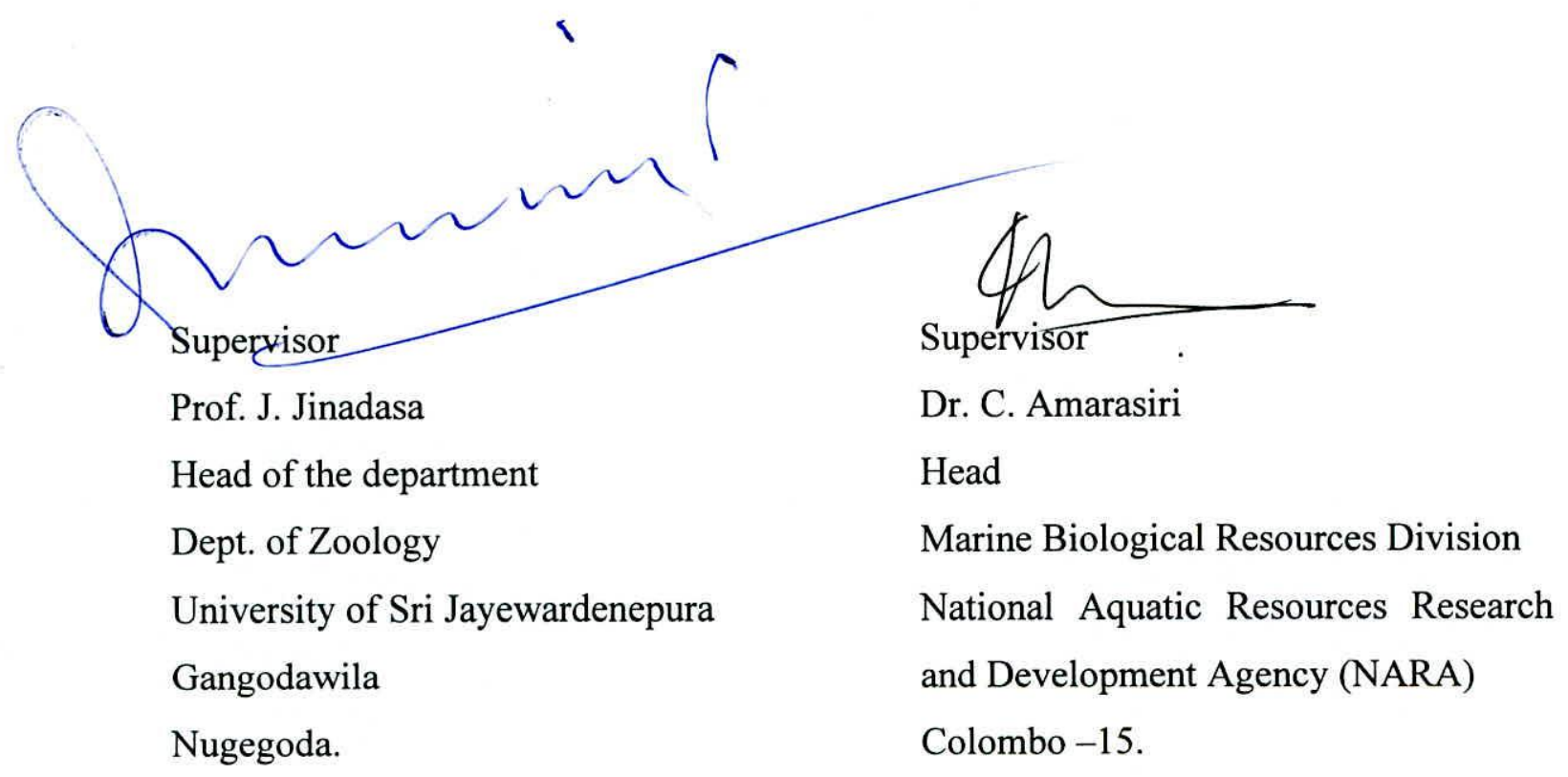


SPECIES IDENTIFICATION OF THE SHARK CATCHES LANDED IN THE WEST COAST OF SRI LANKA WITH SPECIAL REFERENCES TO THE SILKY SHARK Carcharhinus falciformis (Bibron,1839)

by

P. D. KAMAL DEWAPRIYA AMARASOORIYA

Thesis submitted to the University of Sri Jayewardenepura for the award of the degree of Master of Philosophy in Zoology on 30 June 1999. 


\section{CONTENTS}

1. Declaration of the author

2. Declaration of the supervisors

ii

3. Title of the thesis

iii

4. Contents

iv

5. List of Tables

v

6. List of Figures

vii

7. Acknowledgements

ix

8. Abstract $x$

9. Introduction 1

10. Materials and Methods 10

$\begin{array}{llr}\text { 11. Results } & 18\end{array}$

$\begin{array}{lll}\text { 12. Discussion } & 97\end{array}$

13. References 113

$\begin{array}{ll}\text { 14. Appendix } & 120\end{array}$ 


\section{LIST OF TABLES}

Table. I. The characters used for the identification of the orders of sharks

Table. II The means and the range of $\mathrm{POB} / \mathrm{POR}$ of sharks in the Orders

Table. III. Characters used for the identification of Squaliformes sharks

Table. IV. Identified species of the order Squaliformes (Dog fish sharks), their names, gear vulnerability, sex ratios, maximum length and number of specimens observed.

Table. V. Identified species of the order Hexanchiformes (cow sharks), their names, gear vulnerability, sex ratio, maximum length and number of specimens observed.

Table. VI. Characters used for the identification of Orectolobiformes shark.

Table. VII. Identified species of the order Orectolobiformes (Carpet sharks), their names, gear vulnerability,sex ratios, maximum length and number observed.

Table. VIII. Characters used for the identification of species of the families Odontaspididae and Pseudocarchariidae.

Table. IX. Charactersused for the identification of species of the family Alopiidae. 
Table. XI. Identified species of the order Lamniformes (Mackerel sharks), their names, gear vulnerability, sex ratios, maximum length and number observed.

Table. XII. Characters used for the identification of species of the family Sphyrnidae

Table. XIII. Charecters used for the identification of the species of the Families Triakidae and Hemigaleidae

Table. XIV. Characters used for the identification of seven "non Carcharhinus" species of the Family Charcharhinidae.

Table. XV. Characters used for the identification of Carcharhinus species of the Family Charcharhinidae.

Table. XVI. Identified species of the order Carcharhiniformes (Ground sharks), their names, gear vulnerability, sex ratios, maximum length and number observed.

Table. XVII. Major species of sharks present in the catches

Table. XVIII. Specification of fishing crafts engaged in shark fishery

Table. XIX. Variation of fishing ground during the period of study

Table. XX. Ranking of the species present in the shark catches landed. 


\section{LIST OF FIGURES}

Page

Fig. 1. Classification of Sharks up to Order Level (after Compagno, 1984)

Fig. 2. Measurements taken for the study and appropriate abbreviations

Fig. 3. The features used for the identification of Hexanchiformes shark

a. Arrangement of the teeth of left semi maxilla

b. Arrangement of the teeth of left semi mandible

Fig. 4. Monthly variations of number of sharks observed

(Silky shark and other sharks).

Fig 5. Monthly variations of number of individuals recorded in major groups of sharks.

Fig.6. Monthly variation of number of units of gears operated per vessel

Fig. 7. Monthly variation of the fishing effort (E) and the catch per unit effort (CPUE) of the large pelagic fishery

Fig. 8. Variation pattern of CPUE with the fishing effort

Fig. 9 . Monthly variation of CPUE of the large pelagic catch and three major species.

Fig. 10. Monthly variation in the total production of the three major varieties of "large pelagic fishery" 
Fig. 11. Total production of major varieties of fishes present in large pelagic catches

Fig. 12. Number of fish of Silky shark C. falciformis caught by different gears according to the length classes.

Fig. 13.a. Areas of fishing during March - May 1993

b. Areas of fishing during June - August 1993

c. Areas of fishing during Sep. - Nov. 1993

d. Areas of fishing during Dec. - Feb. 1993

e. Areas of fishing during March -May 1994

f. Areas of fishing during June - Aug. 1994

g. Areas of fishing during Sep. - Nov. 1994

h. Areas of fishing during Dec. - Feb. 1993

Fig. 14. Monthly length frequency distribution of Carcharhinus falciformis during the study period with the estimated growth curves

Fig. 15. Length converted catch curve of Carcharhinus falciformis

Fig. 16. probability of capture analysis of Carcharhinus falciformis

Fig. 17. Recruitment pattern of Carcharhinus falciformis 


\section{ACKNOWLEDGMENT}

I am grateful to Prof. J.Jinadasa of University of Sri Jayawardenepura, for his careful guidance and advice throughout this study.

I am also grateful to Dr. P. Dayaratne, former director of Marine Biological Resources Division(MBRD) of National Aquatic Resources Research and Development Agency (NARA) and Dr. C. Amarasiri, Head of MBRD of NARA for their guidance, advice and helping me in numerous other ways.

Special thanks are due to Dr. W. P. N. Karunasinghe and Mr. P. A. A. T. Jayawardane of NARA for their valuable suggestions and critically going through some chapters of this thesis.

I am especially thankful to National Aquatic Resources Research and Development Agency (NARA) for providing me with laboratory, library, financial and other facilities.

I wish to thank Mr. L. Joseph for providing some important published and unpublished literature.

I also wish to thanks Mr. M. G. K. Gunawardane, Mr. H. A. R. E. Perera for their assistance in the field work.

The assistance given by Mrs. W. C. S. Perera, R. N. Senadeer, Mr. U. W. S. Adikari and Miss. D. H. S. L. Wimalasiri in formatting and printing the thesis is highly acknowledged. 


\title{
SPECIES IDENTIFICATION OF THE SHARK CATCHES LANDED IN THE WEST COAST OF SRI LANKA WITH SPECIAL REFERENCES TO THE SILKY SHARK Carcharhinus falciformis (Bibron,1839)
}

by

\section{P. D. KAMAL DEWAPRIYA AMARASOORIYA}

\begin{abstract}
This study was based on the catch sampling of gill net and long line fisheries carried out at Negombo - Pitipana fish landing centre. Additional observations were also made at the Beruwala fish landing center regarding pecies identification. This study revealed the occurrence of 48 species of pelagic and demersal sharks belonging to 5 orders, 15 families and 26 genera in the catches landed in the west coast of Sri Lanka.
\end{abstract}

The orders identified were Hexanchiformes, Squaliformes, Orectolobiformes, Lamniformis and Carcharhiniformes.

The most diverse order among them was Carcharhiniformes. It comprised 4 families, 13 genera and 29 species. The identified families of this order were Triakidae, Hemigaleidae, Carcharhinidae and Sphyrnidae. 
Among the identified species belonging to this order, there were two Mustelus species $M$. manazo, and M. mosis, 14 Carcharhinus species C. albimarginatus, C. altimus, C. amblyrhynchos, C. amboinensis, C. brevipinna, C.falciformis, C. hemiodon, C. limbatus, C. longimanus, C. macloti, C. melanopterus, C.plumbius, C. sorrah, C. wheelery, and 3 Sphyrna species $S$. lewini, S. mokarran and S. zygaena. The other genus comprised one species per each, Hemipristis elongatus, Galeocerdo cuvier,Lamiopsis temminki, Loxodon macrorhinus, Negaprion acutidens, Prionace glauka, Rhizoprionodon acutus, Scoliodon laticudus, Trionodon obesus, and Eusphyra blochii,.

The second most diverse order in the catches was Lamniformes and it comprised 4 families, 4 genus and 8 species. The families were Odontaspididae, Pseudocarchariidae, Alopiidae and Lamnidae.

There were two Odontaspis species, O. noronhai and $O$. ferox, three Alopias species, A. pelagicus, A. superciliosus and A. vulpinus and two Isurus species I. oxyrinchos and I.paucus. There was one species belonging to the genus Pseudocarcharias and that was P.kamoharai.

The number of families and genera present in the order Orectolobiformes were same as in the order Lamniformes (4 and 4), but the number of species identified were 5 . The families of this order were Hemiscylliidae, Ginglymostomatidae, Stegostomatidae and Rhiniodontidae.

Two of the identified species in this order belonged to the genus Chiloscyllium. They were $C$. griseum and $C$. indicum. The other three genus comprised one species each namely, Nebrius ferrugineus, Stegostoma fasciatum and Rhiniodo typus. 
The order Squalidae comprised 2 families, 4 genera and 5 species. The identified families of this order were Echinorhinidae and Squalidae. The former family comprised one species Echinorhinus brucus and the latter comprised 4 species of 2 genera namely, Centrophorus moluccensis, C. uyato, Centroschyllium ornatum and Dalatias licha.

The least diverse order in the catches observed was Hexanchiformes. It comprised only one family (Hexanchidae), one genus and one species Hexanchus griseus.

Out of the above 2 families, Psedocarchariidae and Squalidae and ten species Centrophorus moluccensis, C. uyato, Centroschyllium ornatum, Hexanchus griseus, Odontaspis noronhai, O. ferox, Psedocarcharhis kamoharai, Isurus paucus, Carcharhinus albimarginatus and $C$. plmbius were found to be hitherto unrecorded taxa from Sri Lanka.

Over $90 \%$ of the sharks landed were belonged to the order Carcharhinidae with Carcharhinus falciformis (75\%) being the most dominant species and it has dominated the catch almost through out the year. The thresher sharks (family Alopiidae) and the hammerhead sharks (family Sphyrnidae) were caught in large numbers during the south-west monsoon periods.

The combination of drift gillnet and longline was the main gear used in the shark fishery and the longline operations declined markdly during the monsoon period. The fishing operations were entirely carried out by the multiday fishing vessels which were over $10 \mathrm{~m}$ in length. The average fishing days per trip was 5 and no. of operations per day was 01 for these vessels. 
Skipjack tuna (Katsuvonus pelamis), Silky shark (C. falciformis) and Yellowfin tuna (Thunnus albacares) were the major species of the large pelagic catches landed. The average CPUE for all the large pelagic species was $266 \mathrm{~kg}$ per operation and that for the above three species were 71,67 and $60 \mathrm{~kg}$ per operation respectively.

The contribution of the major species of the large pelagics, Skipjak tuna, Silky shark and Yellowfin tuna Thunnus albacares to the estimated annual total production was 29\%, 25\% and $22 \%$ respectively. However over $33 \%$ of the total catch was made up of the sharks.

Forty three percent of the total number of Silky sharks were caught in gillnets and $57 \%$ were caught in long lines. Size of the fish caught by gill nets ranged from $65 \mathrm{~cm}$ to $255 \mathrm{~cm}$ and that of the long line from $75 \mathrm{~cm}$ to $285 \mathrm{~cm}$. The mean length and standard deviation for the gill net catch were $125.15 \mathrm{~cm}$ and 33.8 while those for the long line catch were $160 \mathrm{~cm}$ and 97.6 .

During the south- west monsoon months, most of the fishing operations were carried out relatively closer to the island, while during the other months, there was a tendency to extend the fishing operations more towards the north-western direction, even beyond the Laccadive islands.

The values for asymptotic length (L8) and growth coefficient (K) estimated for the stock of silky shark were $325 \mathrm{~cm}$ and 0.3 year $^{-1}$ respectively. The instantaneous total mortality coefficient $(\mathrm{Z})$ was 1.68 , the natural mortality coefficient $(\mathrm{M}) \quad$ was 0.42 , and the fishing mortality coefficient $(\mathrm{F})$ 1.26. The catchability coefficient for the gill net and longline combination gear was $5.6 * 10^{-5}$. 
The recruitment pattern of $\boldsymbol{C}$. falciformis during the study period shows one peak around late July early August. The estimated exploitation rate (E) was 0.75 for the existing silky shark fishery. As the present level of exploitation seems to be high, it is suggested that management measures are needed to sustain the stock. 